\title{
O Uso de Documentos Eletrônicos na Contabilidade
}

\author{
Eduardo Cesar Pasa \\ Mestrando em Controladoria e Contabilidade - FEA/USP \\ Analista Sênior da Unidade Contadoria do Banco do Brasil S.A.
}

O objetivo deste artigo é tecer algumas considerações a respeito dos documentos eletrônicos utilizados na contabilidade das empresas.

O artigo inclui uma rápida descrição de como esta matéria vem sendo tratada por alguns órgãos normatizadores e instituições dos Estados Unidos da América. Também, o artigo pretende conceituar e verificar os fundamentos dos documentos, dos documentos eletrônicos e, por fim, dos documentos contábeis. Neste sentido, foram verificados alguns dispositivos legais que amparam o uso deste tipo de documento, bem como a situação de alguns projetos de leis que disciplinam esta matéria.

Os resultados mostram um momento de transição, coerente com a mudança de paradigmas que está ocorrendo na chamada nova economia. Também revelam alguns problemas, tais como a falta de legislação específica que dê suporte ao uso dos documentos eletrônicos na contabilidade.

Palavras-chave: Documento Eletrônico, Documento Contábil, Assinatura Digital, Documento Digital, Escrituração por Processamento Eletrônico de Dados.
The main objective of this article is to elaborate some thoughts on electronic documents used in corporate accounting.

This article is a quick summary of how electronic documents have been treated by corporate regulatory agencies in the USA. The article also intends to create concepts and verify the foundations of the documents, that is, electronic documents and accounting documents. Therefore, rules and laws were verified, as well as Law Projects related to the issue.

The results show a transition period in accordance with paradigm changes, which are a result of the new economy. Additionally, it reveals some problems such as a lack of specific legislation in the use of electronic documents in accounting.

Key words: Electronic Document, Accounting Document, Digital Signature, Bookkeeping by Electronic Data Processing. 


\section{INTRODUÇÃO}

O cenário de mudanças aceleradas no mundo globalizado e a competitividade dos mercados exigem combinações de diferentes inovações tecnológicas e, conseqüentemente, grande capacidade de reação das Empresas.

Por décadas, a tecnologia tem alterado drasticamente a forma com que as empresas fazem negócios. Não faz muito tempo que os computadores pessoais, máquinas de fax, microfilmes, celulares e outros avanços tecnológicos são encontrados no ambiente das empresas e vêm sendo utilizados pelas mesmas, com a finalidade de conseguir um diferencial competitivo e manter ou, até mesmo, aumentar a sua fatia no mercado.

A Tecnologia de Informação é mais uma dessas inovações tecnológicas utilizadas pelas empresas que, mais do que um agente de comunicação e informação, é a base fundamental dessa revolução e está modificando radicalmente o modo tradicional de se fazerem negócios, abrindo oportunidades de operar de forma mais eficiente e providenciar melhores serviços aos clientes dessas empresas.

A internet, os documentos e dados digitais, EDI (Intercâmbio de dados eletrônicos), gerenciamento de documentos eletrônicos, workflow entre outros, são exemplos dessas tecnologias que estão sendo utilizadas pelas empresas como meio de disponibilizar as informações e que estão alterando a forma de gerenciar as empresas, dando um conjunto de suporte aos negócios por elas realizados.

Com isso, essas novas tecnologias têm impactado, sobretudo, a forma de fazer contabilidade nas empresas. A tecnologia de informação continuará alterando as empresas, principalmente trazendo novas tecnologias que irão modificar os processos contábeis, bem como novos caminhos para os usuários de informações recolherem e analisarem a informação.

\section{UMA VISÃO DO FUTURO - MELHORANDO A INFORMAÇÃO}

Anualmente, o AICPA (Instituto Americano de Contadores Públicos Certificados) divulga as 10 mais importantes tecnologias que afetam a indústria contábil' . A lista para o ano de 2000 inclui basicamente as preocupações que envolvem o uso da Internet nas operações das empresas. Entre os dez assuntos relacionados na lista, podem-se citar, por exemplo: 0 comércio eletrônico (eBusiness), o controle e segurança da informação e o relatório financeiro eletrônico.

Na linha do comércio eletrônico são incluídos todos os processos tecnológicos que permitem acessar, atualizar e comunicar as informações do negócio puramente no formato eletrônico, as quais poderão ser mais eficientemente utilizadas, criando assim, vantagens competitivas.

O controle e a segurança da informação estão relacionados com os software, processos, procedimentos e hardware utilizados para que as informações possam ser avaliadas somente por pessoas autorizadas a acessá-las. A autenticação, o não-repúdio e o certificado digital são alguns conceitos utilizados que permitem às empresas controlar e assegurar as informações no meio digital e serão discutidos mais à frente.

Os relatórios financeiros eletrônicos envolvem processos e tecnologias que permitem disponibilizar as informações financeiras no formato digital.

Particularmente, também o FASB (Financial Accounting Standards Board) reconhece a importância da tecnologia no futuro dos relatórios financeiros. Assim, instituiu o BRRP (Business Reporting Research Project ${ }^{2}$ ). Neste projeto ${ }^{3}$ foi designado um grupo de pessoas que pesquisaram a distribuição eletrônica dos relatórios de informações das empresas. Basicamente, foi avaliada a distribuição dos mesmos utilizando a Internet.

A SEC (Securities and Exchange Commission) também tem demonstrado interesse na divulgação das informações financeiras por meio de documentos eletrônicos. Neste sentido, implantou o sistema EDGAR (Electronic Data Gathering, Analysis, and Retrieval). O EDGAR é um sistema que apresenta uma coleção de dados, indexados, validados e aceitos, de formulários entregues à SEC, por força da lei, pelas empresas. A principal proposta deste sistema é aumentar a eficiência e a transparência dos

\footnotetext{
1 Divulgado no site WWW.toptentechs.com

2 Projeto de pesquisa dos relatórios das empresas

${ }^{3}$ Divulgado no site WWW.FASB.ORG
} 
mercados financeiros, beneficiando o investidor, as empresas e a economia, agilizando o recebimento, a concordância, a disseminação e a análise das informações corporativas que estão armazenadas nesta agência.

Desta forma, note-se uma apreensão por parte desses órgãos, a propósito do impacto que a tecnologia de informação vem gerando sobre a contabilidade, especialmente sobre os aspectos da disponibilização das informações das empresas na forma digital pela contabilidade. Esta disponibilização se dá através do uso do que chamamos de documentos eletrônicos ou documentos digitais.

Para entender claramente esses impactos e assim situarmos o documento eletrônico na contabilidade, devemos conceituar e verificar os fundamentos dos documentos, dos documentos eletrônicos e, por fim, dos documentos contábeis.

\section{DOCUMENTO}

Toda a informação contida em um suporte material que contenha a propriedade de ser comunicada é um documento. É "qualquer base de conhecimento, fixada materialmente e disposta de maneira que se possa utilizar para consulta, estudo, prova etc."4, como o definem os dicionários.

Contudo, é mais do que um suporte material que recebe um assentamento gráfico com carga informativa, pois se trata da reprodução de determinada manifestação do pensamento humano. Observa-se, assim, sempre a presença de um receptor no fenômeno comunicativo, sem o que não se teria propriamente um documento.

Neste sentido, o documento pode ser definido como "uma fonte aceite, fixa e permanente de informação corretamente assimilada" ${ }^{\text {. Contudo, não }}$ se pode ignorar o fato de que o conceito de documento deriva da necessidade de transmitir informações e não propriamente da forma em que o processo se dá.

Não se busca um conceito minucioso de documento, e sim a inserção de elementos básicos para fundamentar um possível conceito de documento no aspecto contábil, ou seja, na identificação daqueles elementos que possam garantir à informação contábil a característica qualitativa da confiabilidade. Um dos aspectos que deve ser analisado é o caráter probatório (autenticidade) dos documentos.

A forma usual da verificação da autenticidade de um documento está fundamentada na segurança da consistência original de seu conteúdo e na identificação da procedência. Para garantir se o conteúdo é original, deve-se verificar a materialidade, ou seja, o suporte em que está inserida a informação. Por sua vez, a procedência pode ser verificada através da identificação da assinatura manuscrita.

O suporte, registra Zagami, "é uma substância que permite a fixação dos signos gráficos no qual é expresso o documento. $O$ mais comum dos suportes à escrituração é a carta, mas os mais variados tipos de suporte são abstratamente concebíveis"6 . Assim, observa-se que os documentos podem ter os mais diferentes meios materiais, bem como formas de expressar os símbolos contidos nos mesmos.

Independente do suporte (base material) em que o documento esteja "escrito", ao analisar o valor probatório do mesmo, é necessário que a base material seja indelével, não permitindo qualquer tipo de adulteração ou cancelamento e, caso ocorram tais eventos, que possam ser identificados os fatos.

Também, faz-se necessária a identificação da procedência da informação de forma segura. Tradicionalmente, verifica-se a procedência da informação com a aposição da assinatura manuscrita, que se presume única para cada indivíduo e difícil de ser reproduzida, não sendo modificável e não permitindo a desvinculação do suporte que a contém para ser reutilizável. Em outras palavras, esta assinatura deve ser parte integrante do documento. $\mathrm{Na}$ contabilidade, é evidente a relevância da assinatura para a identificação da procedência do documento.

Dada a importância da documentação dos atos, principalmente como meio posterior de prova, verificase que as formas de muitos documentos estão previstas em lei e, praticamente todas estão relacionadas com conceitos decorrentes da

\footnotetext{
${ }^{4}$ Cf. Novo Dicionário Aurélio. O conceito etimológico se liga a documentum que se radica em docere, que significa ensinar. Aurélio Buarque de Holanda FERREIRA, Novo dicionário da língua portuguesa, 1986.

5 Antonio Luis García GUTIÉREEZ. Lingüística Documental. Barcelona : Mitre, 1989, p. 49.

${ }^{6}$ Raimondo ZAGAMI. Firme 'Digitali', Crittografia e Validità del Documento Elettronico. In “Il Diritto dell'informazione e dell'informatica”, 1996 , fasc. 1, p. 151.
} 
documentação em papel. De fato, as exigências de forma "escrita", "assinada" e em "original" (exigidas para certos atos solenes) partem do pressuposto de que os atos jurídicos são registrados tendo o papel como suporte material.

Portanto, a forma tradicional de idealizar um documento faz uso do papel como suporte material. $\mathrm{E}$, conseqüentemente, da assinatura manuscrita como forma de garantir a procedência do documento.

Observa-se que esta forma tradicional parte da premissa de que qualquer alteração do documento em papel pode ser identificada e que a assinatura manuscrita é única e de difícil reprodução por outrem, a não ser pelo próprio emissor do documento.

Com efeito, um documento em papel tem diversas funções, tais como: garantir uma tangível evidência da existência da vontade contratual das partes; providenciar para que possa ser lido por todos; possibilitar que permaneça inalterado ao longo do tempo e fornecer um permanente registro da transação, permitindo sua reprodução por meio da extração de cópias; permitir a autenticação por meio de uma assinatura; permitir o fácil arquivamento dos dados em forma tangível e facilitar o controle e auditagem para fins de contabilidade, tributação ou outros propósitos regulatórios. Assim, a exigência da apresentação de documento em papel na forma escrita, que pode ser combinada com outros requisitos, como assinatura e apresentação na forma original, ou ainda a autenticação legal do ato, visam a emprestar maior confiabilidade e segurança jurídica ao documento.

Com isso, a forma tradicional alcança o valor probatório exigido pela confiabilidade, uma das características qualitativas da informação contábil.

\section{DOCUMENTO ELETRÔNICO}

Conforme observado anteriormente, o papel não é o único suporte material possível do documento e, em conseqüência, a forma e os símbolos utilizados para reproduzir o pensamento humano. Assim, a fixação da informação poderá ser, por exemplo, em discos ópticos, ou seja, no meio digital. Em decorrência, o símbolo pode ser constituído de elementos básicos da informação eletrônica, como por exemplo bits.

Pode-se conceituar o documento eletrônico como o documento que tem como suporte material o meio eletrônico.

Esta alteração do suporte material do papel para o meio eletrônico oferece rapidez e agilidade no trânsito de informações, pois as informações em forma de bits poderão trafegar praticamente na velocidade da luz, reduzindo os espaços e os custos na sua conservação.

Para ilustrar melhor a redução do espaço, um CDROM possui a capacidade de armazenar 13.600 páginas de documentos. ${ }^{7}$

No entanto, esta alteração de suporte deve satisfazer no mínimo o exato grau de segurança que os documentos em papel oferecem, o que deve ser alcançado através de uma série de recursos técnicos.

Um dos requisitos básicos é a exigência de que a informação contida no documento eletrônico esteja acessível para consulta posterior. O termo "acessível" focaliza a necessidade indispensável de que a informação possa ser reproduzida e lida, do mesmo modo como ocorre com um documento em papel, ou seja, em uma forma universal possibilitando a democratização da informação.

Outro requisito de segurança é a identificação da procedência, ou seja, identificar a pessoa e indicar que a mesma aprovou a informação contida no documento.

Também, outro ponto fundamental é que se deve garantir a consistência do conteúdo original. Cabe ressaltar que a figura do documento original deixa de existir, pois todo documento eletrônico é original, ou seja, é único. Desta forma, o que se busca garantir é a integridade da informação quando do envio da mesma para o destinatário.

Estes requisitos estão relacionados com o valor probatório dos documentos eletrônicos. Como foi visto anteriormente, o valor probatório dos documentos está em garantir a consistência do conteúdo original e a identificação da procedência do mesmo.

A tecnologia de documentação eletrônica tem um recurso que se propõe a assegurar a consistência do conteúdo original e a identificação da procedência ao mesmo tempo. Este recurso é conhecido como firma digital ou assinatura digital.

Com a aplicação da assinatura digital no documento eletrônico é possível assegurar que o conteúdo original não seja adulterado, bem como

\footnotetext{
${ }^{7}$ Don M. AVEDON, GED de A a Z : tudo sobre gerenciamento de documentos, 1999, p.36.
} 
identificar a procedência do documento, atingindo a plena eficácia probatória dos documentos.

Assim, o documento eletrônico com a devida firma digital aposta é seguro, confiável, melhor administrável no sentido do seu armazenamento e recuperação, e a sua comunicação é muito mais eficiente e rápida, além de segura.

\subsection{Assinatura Digital}

A ONU (Organizações das Nações Unidas) criou em 1996 a UNCITRAL (Comissão sobre Leis Internacionais de Comércio das Nações Unidas) com a finalidade de promover a unificação e harmonização das leis internacionais de comércio. Esta comissão desenvolveu um modelo de lei sobre o comércio eletrônico, fornecendo alguns parâmetros que deveriam ser observados pelos países membros, quando da formulação de suas leis sobre este assunto. Este modelo prevê o uso de documentos eletrônicos para a comunicação e guarda da informação.

O artigo $7^{\circ}$ do Modelo de Lei ${ }^{8}$ das Nações Unidas sobre o comércio eletrônico assim estabelece sobre a assinatura:

"Where the law requires a signature of a person, that requirement is met in relation to a data message if:

(a) a method is used to identify that person and to indicate that person's approval of the information contained in the data message; and (b) that method is as reliable as was appropriate for the purpose for which the data message was generated or communicated, in the light of all the circumstances, including any relevant agreement."

Deste modo, fica claro que a assinatura é uma marca individual feita com a finalidade de autenticar um documento. Ao assinar um documento, um indivíduo realiza quatro gestos fundamentais: intenção, afirmação, evidência e cerimônia. O primeiro gesto corresponde ao compromisso do indivíduo com o texto descrito no documento. O segundo é a confirmação de que esta transação foi consumada.
O terceiro indica a vinculação do indivíduo ao documento. E, por fim, com o quarto gesto, o indivíduo assume todas as conseqüências legais desta ação.

Para que se possa assegurar que o conteúdo original não seja adulterado, bem como identificar a procedência do documento eletrônico, o mesmo deverá ser digitalmente assinado. Contudo, somente serão verdadeiras essas afirmações, desde que a assinatura digital:

- seja única e exclusiva para o documento assinado;

- seja passível de verificação;

- seja gerada sob controle exclusivo do signatário;

- esteja de tal modo ligada ao documento eletrônico que, em caso de posterior alteração deste, a assinatura seja invalidada; e

- não tenha sido gerada posteriormente à expiração, revogação ou suspensão das chaves.

Segundo Zagami, uma assinatura digital "é um conjunto de caracteres alfanuméricos resultante de complexas operações matemáticas de criptografia efetuadas por um computador sobre um documento eletrônico (um texto, uma imagem, um som ou qualquer outro arquivo digital)"10.

Criptografia (kriptós = escondido, oculto; grápho = grafia) : é a arte ou ciência de escrever em cifra ou em código, de forma a permitir normalmente que apenas um destinatário a decifre e a compreenda. Quase sempre o deciframento requer uma chave, uma informação secreta disponível ao destinatário. Logo, a encriptação é a transformação de dados em uma forma ilegível por qualquer pessoa sem o uso de uma chave secreta de decriptação. A sua finalidade é assegurar a privacidade, tornando a informação oculta a qualquer pessoa a que não seja especificamente dirigida.

A autenticação de um documento eletrônico se dá através da aposição da assinatura digital no documento. Trata-se de um processo eletrônico por meio do qual o receptor de uma mensagem eletrônica pode se assegurar da identidade do remetente e/ou da integridade da mensagem.

Existem basicamente dois sistemas de encriptação

\footnotetext{
${ }^{8}$ UNCITRAL Model Law on Electronic Commerce.

${ }^{9}$ Onde a lei requer a assinatura de uma pessoa, este requerimento é cumprido relação a uma mensagem de dados se: a) um método é utilizado para identificar esta pessoa e indicar a aprovação desta pessoa da informação contida nesta mensagem de dados; b) este método é confiável como também apropriado para o propósito a que a mensagem de dados foi gerada e comunicada, à luz de toda circunstância, incluindo qualquer acordo relevante.

10 Op.Cit. p. 152
} 
de dados: (a) sistema simétrico, que utiliza uma única chave para encriptação e decriptação da mensagem; (b) sistema assimétrico, quando se requer a aplicação de diferentes chaves para a operação de encriptação e decriptação da mensagem.

O sistema assimétrico de encriptação é o sistema que possibilitou a criação das assinaturas digitais, pois garante a integridade do documento eletrônico e identifica a procedência dos mesmos.

A criptografia que utiliza o sistema assimétrico é também conhecida como criptografia de chave pública. Alguns padrões internacionais utilizam este sistema, como: ISO 9796 (Organização de Padrões Internacionais), ANSI X9.31 (Instituto Americano de Padrões Nacionais), ITU-T X.509 (União Internacional de Telecomunicações), PKCS (Padrões de Criptografia de Chave Pública), SWIFT (Sociedade para as Telecomunicações Financeiras Interbancárias Mundiais), ETEBAC № 5 (Sistema Financeiro Francês), entre outras.

Nos sistemas com chave pública, qualquer pessoa pode cifrar uma mensagem, mas somente o destinatário da mensagem pode decifrá-la. Invertendose o uso das chaves podemos ter uma mensagem que só pode ser cifrada por uma pessoa e decifrada por qualquer um, obtendo-se assim um efeito de personalização do documento, semelhante a uma assinatura; por isso tem sido denominada assinatura digital. Assim, para personalizar uma mensagem, um determinado usuário A codifica uma mensagem utilizando sua chave secreta e a envia para o destinatário. Somente a chave pública de A permitirá a decodificação da mensagem por ele enviada, portanto, é a prova de que A enviou a mensagem.

As seguintes propriedades são encontradas no sistema de chave pública:

1 - a assinatura é autêntica: quando um usuário utiliza a chave pública de A para decifrar uma mensagem, ele confirma que foi A e somente A quem enviou a mensagem;

2 - a assinatura não pode ser forjada: somente A conhece sua chave secreta;

3 - o documento assinado não pode ser alterado: se houver qualquer alteração no texto criptografado este não poderá ser restaurado com o uso da chave pública de $\mathrm{A}$;

4 - a assinatura não é reutilizável: a assinatura é uma função do documento e não pode ser transferida para outro documento;
5 - a assinatura não pode ser repudiada (não repúdio): o usuário $B$ não precisa de nenhuma ajuda de $A$ para reconhecer sua assinatura e $A$ não pode negar ter assinado o documento.

Observa-se, assim, que o funcionamento da encriptação assimétrica ou chave pública decorre do uso de um algoritmo que utiliza pares de chaves: uma encripta a mensagem, outra decripta. Uma das chaves será tornada pública (chave pública) com a sua inserção em repositórios públicos de chaves (bancos de dados que podem tornar disponíveis as chaves públicas - inclusive pela internet), associando-a ao nome de um titular e outras características capazes de identificá-lo. A outra (chave privada) é de custódia secreta do titular e representa o algoritmo utilizado para encriptar o documento eletrônico. Portanto, uma assinatura digital resulta da aplicação de uma chave privada sobre um documento eletrônico. Assim, qualquer um que receba esse documento e queira verificar a sua procedência e integridade, deverá aplicar sobre ele a chave pública correspondente, certificando-se, assim, da sua autenticidade.

Portanto, o sistema de assinatura digital exige que cada entidade (empresas, pessoas, governos) possua duas chaves de criptografia: a chave privada (custodiada pela entidade) e a chave pública (custodiada por um repositório público).

Para demonstrar de forma prática o uso da assinatura digital sobre um documento eletrônico, supõe-se a concessão de um empréstimo por um banco a uma pessoal que se encontra em sua residência. $\mathrm{O}$ banco $\mathrm{W}$ envia pela Internet o contrato encriptado com sua chave privada para a pessoa $X$; esta pessoa $X$, ao receber o contrato encriptado, aplica a chave pública do banco $\mathrm{W}$, e se a verificação é positiva, a pessoa $X$ terá a certeza de que a mensagem provém do banco $\mathrm{W}$ (identificação da procedência) e que não sofreu qualquer tipo de adulteração devida a erro de transmissão ou interpolação de texto (integridade). Ao analisar o contrato e resolver tomar o empréstimo, a pessoa $X$ envia pela Internet o contrato encriptado com sua chave privada para o banco $\mathrm{W}$; o banco $\mathrm{W}$ ao receber o contrato encriptado aplica a chave publica da pessoa $\mathrm{X}$, e se a verificação for positiva, o banco $\mathrm{W}$ terá a certeza de que o contrato provém da pessoa $X$ (identificação de procedência) e que não sofreu qualquer tipo de adulteração (integridade) e, 
finalmente, a pessoa $X$ não poderá sustentar que não enviou o contrato (não repúdio) e o Banco W poderá liberar o valor contratado no empréstimo.

Outro aspecto importante da assinatura digital é que através dela é possível garantir o caráter confidencial dos documentos, ou seja, no exemplo anterior, somente o banco $\mathrm{W}$ e a pessoa $\mathrm{X}$ podem ter acesso ao contrato de empréstimo, pois o mesmo encontra-se criptografado com as chaves privadas de ambos.

\subsection{Selo Cronológico Digital}

Outra importante ferramenta utilizada no documento eletrônico é o Selo Cronológico Digital. Tem como finalidade ser usado futuramente para provar que um documento eletrônico existia na data alegada. Para isso, o selo cronológico digital associa uma data e uma hora a um documento eletrônico em uma forma de criptografia.

O uso do Selo Cronológico Digital parece ser extremamente importante, se não essencial, para manter a validade de documentos através dos anos. Suponha um contrato de leasing de vinte anos entre um proprietário de máquinas e um arrendatário. As chaves públicas usadas para assinar o contrato expiram após um ano. Soluções como reafirmar as chaves ou reassinar o contrato a cada ano, com novas chaves, requerem a cooperação de ambas as partes durante vários anos enquanto durar o contrato. Se uma das partes se torna insatisfeita com o contrato, ela pode recusar-se a cooperar. A solução é registrar o contrato com o Selo Cronológico Digital na data da primeira assinatura deste. Ambas as partes recebem então uma cópia do selo cronológico, que pode ser usada anos mais tarde para comprovar a autenticidade do contrato original.

\section{DOCUMENTO CONTÁBIL}

Como explicitado anteriormente, o documento é qualquer base de conhecimento, fixada materialmente e disposta de maneira que se possa utilizar para consulta, estudo, prova etc.

Portanto, documento contábil é toda a informação emanada pelo conhecimento contábil, bem como os documentos utilizados para realizar a escrituração.

Muitos foram os documentos contábeis gerados e utilizados pelo homem no trabalho de informar e controlar as coisas e os objetos que possuía. Podese observar o uso de documentos contábeis por volta de 8000 a.C. Segundo Mattessich ${ }^{11}$, as descobertas da professora Denise Schmandt-Besserat, entre 1969 e 1993, de símbolos de argila de diferentes formas, eram na realidade documentos contábeis, pois eram utilizados como representações de um agregado de mercadorias devido por uma pessoa a outra.

Já Menninger ${ }^{12}$ observou que, desde o século XII, o Tesouro Britânico fazia uso dos tally stick, isto é, pedaços de madeira com marcas de cortes que possuem inúmeras funções. Quando utilizados como registro contábil chamavam-se number sticks e tinham a força de um documento legal.

O mesmo autor relata ainda as cordas de nós do $\mathrm{Peru}^{13}$, denominadas quipus. Travava-se de uma forma primitiva de manter os registros financeiros do Império Inca.

Não se tem a intenção de esgotar todas as formas de documentos contábeis existentes na história da humanidade, mas acredita-se que é possível perceber o uso de diversos suportes materiais na representação do pensamento humano, principalmente no conhecimento contábil.

Com a finalidade de identificar com mais clareza os documentos contábeis, é importante destacar as definições das Normas Brasileiras de Contabilidade:

"NBC T 2.2 - Da Documentação Contábil 2.2.1 - A Documentação Contábil compreende todos os documentos, livros, papéis, registros e outras peças, que apóiam a escrituração contábil.

2.2.1.1 - O Documento contábil, estrito-senso, é aquele que comprova os atos e fatos que originam lançamento(s) na escrituração contábil da Entidade.

2.2.2 - A Documentação Contábil é hábil, quando revestida das características intrínsecas ou extrínsecas essenciais, definidas na legislação, na técnica contábil

\footnotetext{
11 Richard MATTESSICH. Critique of accounting: examination of the foundations and normative structure of an applied discipline, 1995.

12 K. MENNINGER, Number words and number symbols: a cultural history of numbers, 1969, p. 236-237.

13 Op. cit., p. 255.
} 
ou aceitas pelos "usos e costumes".

2.2.3 - A Documentação Contábil pode ter origem interna quando gerada na própria Entidade, ou externa quando proveniente de terceiros.

2.2.4 - A Entidade é obrigada a manter em boa ordem a documentação contábil.".

Assim, conclui-se que os documentos contábeis incluem tantos os documentos gerados pela empresa (lançamentos contábeis, demonstrativos financeiros etc) bem como os provenientes de terceiros (documentos que comprovam os lançamentos contábeis, também conhecidos como documentos probatórios).

Também, para serem considerados documentos contábeis, os mesmos deverão atender algumas características essenciais definidas na legislação ou em normas contábeis.

Verifica-se agora o valor probatório dos documentos contábeis. Aplicam-se aqui todos os prérequisitos dos documentos. Assim, os documentos contábeis devem estar em suporte material indelével e deve ser possível identificar a sua procedência.

Segundo Hendriksen ${ }^{14}$, a objetividade é uma restrição, principalmente, de mensuração. O mesmo autor destaca que o conceito de objetividade tem sido distinto para diversos autores. Contudo, apresenta algumas convergências nas definições: "1. mensurações e avaliações de caráter impessoal ou que se configuram fora do pensamento da pessoa ou pessoas que as estão realizando; 2 . mensurações baseadas no consenso profissional de EXPERTS qualificados; 3. mensuração e avaliações baseadas em evidências e documentação verificável; 4. valor da dispersão estatística das mensurações de um atributo, quando efetuadas por vários pesquisadores.". Neste sentido, destaca-se a importância da documentação contábil, que, em alguns momentos, significa uma restrição no processo de mensuração.

Nesta mesma linha, o IBRACON ${ }^{15}$ através do pronunciamento "Estrutura Conceitual Básica da Contabilidade", define os Princípios Contábeis Geralmente Aceitos. Neste documento, é apresentada de uma forma mais prática e profissional a convenção da objetividade: "A contabilidade, em igualdade de procedimentos quanto à sua relevância, preferirá os que puderem ser suportados por algum tipo de evidência considerada objetiva (documentos, normas escritas, consenso profissional etc.)". Novamente, observa-se a relação da documentação como forma de comprovação dos atos e fatos contábeis interferindo no processo de mensuração.

Ao analisar a Lei o 486, de 03/03/1969 no seu artigo $2^{\circ}$, nota-se a preocupação do legislador quanto ao aspecto de integridade do documento contábil gerado pela empresa:

"Art. 2o - A escrituração será completa, (...), com clareza, por ordem cronológica de dia, mês e ano, sem intervalos em branco, nem entrelinhas, borraduras, rasuras, emendas e transportes para as margens"

Do mesmo modo, o valor probatório do documento contábil é explicitado no Decreto-Lei ㄲo 24.337, de 14/01/1948; no artigo 1ํ, o legislador preocupou-se em definir o requisitos:

"Art. 1 - Os balanços, demonstrações de contas de lucros e perdas, extratos, discriminações de contas ou de lançamentos e quaisquer outros documentos de contabilidade, exigidos pelas repartições fiscais, para fins do imposto de renda ou para quaisquer outros fins, só poderão fazer prova na conformidade da legislação, quando assinados por contador ou guarda-livros registrado em Conselho Regional de Contabilidade, com a indicação do número do registro."

Na Resolução CFC no 825/98, de 30/06/1998, artigo $20, \S 2^{\circ}$, é ratificado este requisito da assinatura do contador no documento contábil de emissão da empresa para que o mesmo tenha valor probatório:

"Art. 20 -

(...)

§ 2으 - Os documentos contábeis somente terão valor jurídico quando assinados por contabilista com a indicação do número de registro e da categoria.

(...)"

\footnotetext{
14 Eldon S. HENDRIKSEN, Teoria da Contabilidade, 1999, p.114-116.

15 FIPECAFI/Arthur Andersen, Normas e práticas contábeis no Brasil, 1994, p.61.
} 
De uma maneira geral, o documento contábil é aquele que comprova os atos e fatos que originam os lançamentos contábeis, bem como os documentos produzidos pelo contador no exercício de suas atividades profissionais.

\subsection{Emissão e Escrituração de Documentos, Livros Fiscais e Contábeis por Processamento Eletrônico de Dados}

Os dispositivos legais da emissão e escrituração de documentos, livros fiscais e contábeis são encontrados principalmente no Decreto-Lei no 486, de 03/03/1969, e no Decreto no 64.567 , de 22/05/1969.

Contudo, a primeira definição legal sobre a escrituração e documentação contábil encontra-se no Código Comercial, Lei no 556 , de 25/06/1850, no seu artigo 10:

"Todos os comerciantes são obrigados: a seguir uma ordem uniforme de contabilidade e escrituração, e ter os livros para esse fim necessários;

....

a conservar em boa guarda toda a escrituração, correspondência e mais papéis pertencentes ao giro do seu comércio, enquanto não prescreverem as ações que possam ser relativas.

...."

O Decreto-Lei № 486, de 03/03/1969, dispõe escrituração e livros mercantis e dá outras providências.

Conforme preceitua o Art. $2^{\circ}$ deste decreto, a escrituração deverá ser completa, em idioma e moeda corrente nacional, em forma mercantil, com individuação e clareza, por ordem cronológica de dia, mês e ano, sem itervalos em branco, nem entrelinhas, borraduras, rasuras, emendas e transportes para as margens. No entanto, é permitido o uso do Código de Números ou de abreviaturas, desde que estes constem de livro próprio, revestido das formalidades estabelecidas no citado diploma legal, ou seja, autenticação dos mesmos.

Cumpre também lembrar que a escrituração ficará sob a responsabilidade do profissional qualificado, nos termos da legislação específica (Contador), exceto nas localidades em que não haja elemento nessas condições, e os erros cometidos serão corrigidos por meio de lançamento de estorno.

Preceituou o citado diploma legal no seu Artigo 50 que é obrigatório o uso de Livro Diário, encadernado, com folhas numeradas seguidamente, em que serão lançados, dia a dia, diretamente ou por reprodução, os atos ou operações da atividade mercantil, ou que modifiquem ou possam vir a modificar a situação patrimonial do comerciante.

O comerciante que empregar escrituração mecanizada poderá substituir o Diário e os livros facultativos ou auxiliares por fichas, seguidamente numeradas, mecânica ou tipograficamente.

E os livros ou fichas do Diário deverão conter termos de Abertura e de Fechamento, e ser submetidos à autenticação do órgão competente do Registro de Comércio, ou seja, as Juntas Comerciais Locais, admitindo-se a escrituração resumida do Diário, por totais que não excedam o período de um mês, relativamente às contas cujas operações sejam numerosas ou realizadas fora da sede do estabelecimento, desde que utilizados livros auxiliares para registro individualizado, e conservados os documentos que permitam sua perfeita verificação.

O Decreto ํo 64.567, de 22/05/1969, regulamentou o Decreto-Lei no 486/69.

Entre outras coisas, o decreto determinou:

a) a individualização da escrituração a que se refere o artigo 2o do Decreto-lei o 486/69 compreende, como elemento integrante, a consignação expressa, no lançamento, das características principais dos documentos ou papéis que deram à própria escrituração;

b) nas localidades onde não houver contabilista legalmente habilitado, a escrituração ficará a cargo do comerciante ou pessoa pelo mesmo designada; sendo essa designação única e exclusiva do comerciante pela responsabilidade pela escrituração para efeitos legais;

c) cabendo aos Conselhos Regionais de Contabilidade informar aos órgãos de Registro do Comércio da existência ou não de profissional habilitado naquelas localidades;

d) só poderão ser usados, nos lançamentos, processos e reprodução que não prejudiquem a clareza e nitidez da escrituração, sem borrões, emendas ou rasuras; 
e) os livros deverão conter, respectivamente, na primeira e na última página, tipograficamente numeradas, os termos de abertura e de encerramento;

f) os termos de abertura e encerramento serão datados e assinados pelo comerciante ou por seu procurador ou por contabilista legalmente habilitado;

g) as fichas que substituírem os livros, para o caso de escrituração mecanizada, poderão ser contínuas, em forma de sanfona, em blocos, com subdivisões numeradas mecânica ou tipograficamente por dobras, sendo vedado o destaque ou ruptura das mesmas;

h) quando o comerciante adotar as fichas, no caso de escrituração mecanizada, os termos de abertura e de encerramento serão apostos na primeira e últimas fichas de cada conjunto e todas as demais serão obrigatoriamente autenticadas como o sinete do Órgão de Registro do Comércio;

i) os casos omissos serão resolvidos pelo Departamento Nacional de registro do Comércio, ouvidos, quando necessário, os órgãos dos Poderes Públicos Federais, por força de suas atribuições, que tenham relação com a matéria.

Um avanço da legislação brasileira foi a Lei no 5.433 , de 08/05/1968, que dispõe sobre a autorização de microfilmar os documentos particulares e oficiais, dando-Ihes os mesmos valores probatórios dos documentos originais. A mesma lei definiu ainda que os documentos microfilmados poderão ser eliminados a critério da autoridade competente.

A instrução Normativa no 18 , de 28/09/1987, do DNRC autorizou os órgãos de Registro do Comércio a autenticar as microfichas gerada pelo processo COM-Computer Output Microfilm (microfichas geradas por microfilmagem de saída direta do computador).

A Secretária da Receita Federal, na Instrução Normativa no 65, de 15/07/93, normatizou a apresentação dos arquivos magnéticos para pessoas jurídicas que utilizam sistemas de processamento eletrônico de dados para escriturar livros e documentos de natureza contábil ou fiscal. Esta instrução foi a primeira, entre muitas, que previam o uso, por parte da Receita, de documentos eletrônicos como forma de obter informações dos contribuintes.

\subsection{Legislação Brasileira sobre Documentos Eletrônicos}

Para que a natureza jurídica do registro de informação e documentação em meio digital deixe de ser considerado cópia, deverá existir uma legislação específica que o considere como um documento original. Isto significa que qualquer documento eletrônico deverá ser autenticado por uma autoridade competente para que produza os mesmos efeitos do documento original.

Assim, é necessário que uma legislação faça a previsão legal do uso da assinatura digital. Para tanto, esta legislação deverá instituir a infraestrutura utilizada para o uso desse recurso. Ao nosso ver, a principal infraestrutura é a criação de autoridade pública certificante das assinaturas digitais utilizadas pelas pessoas e empresas; em outras palavras, a criação de cartórios com finalidade de certificar os documentos eletrônicos.

Observa-se que é permitido o uso de mídia eletrônica para o registro de negócios e atividades econômicas, escrituração de livros contábeis e elaboração de documentos de natureza contábil e fiscal. No entanto, a Receita Federal e o DNRC fazem as seguintes exigências: 1) os arquivos e sistemas têm de ser conservados pelo contribuinte pelo prazo de 5 anos; e, 2) é obrigatória a escrituração ou emissão dos Livros Diários e do Razão, por escrita tradicional ou através de microfichas (microfilmes).

Completando o assunto, é oportuno observar que a Lei oㅜ 8.934. de 18/11/1994 e o Decreto oㅜ 1.800, de 30/01/1996, que a regulamenta, dispõem sobre 0 Registro Público de Empresas Mercantis e Atividades afins e prevê o uso de meios tecnológicos mais avançados para preservar a imagem dos documentos.

Também a Lei oㅡ 8.935, de 18/11/1994, que dispõe sobre serviços notoriais e registros, preceituou o uso de outra forma de documentação (além do papel e do microfilme) pelos Notários e Oficiais de Registros em suas atividades.

Contudo, destaca-se que os documentos contábeis eletrônicos, por apresentarem valor jurídico, necessitarão de uma lei ordinária que os amparem. Assim, nota-se uma demanda da área contábil por legislação que abordem os aspectos jurídicos da digitalização de arquivos e da disponibilidade, confidencialidade, autenticidade, integridade, não repudio da Informação na forma digital. 
Atualmente, encontram-se alguns Projetos de Lei que estão tramitando no Congresso Nacional. Os Projetos de Lei no 1483/99 , oo 1589/99 e oㅜ 3173/97 estão tramitando na Câmara de Deputados Federal, e o Projeto de Lei do Senado no 00672/99 está tramitando no Senado Federal, todos relacionados com o comércio eletrônico. Já os Projetos de Lei no 0022/96, atual Projeto de Lei no 3173/97 na Câmara de Deputados, e no 1532/99 estão relacionados com a digitalização dos documentos.

O Projeto de Lei no 1483/99 do Deputado Hélio de Oliveira Santos pretende instituir a fatura eletrônica e a assinatura digital nas transações de comercio eletrônico, e dispõe:

- fica instituída a fatura eletrônica assim como a assinatura digital, nas transações comerciais eletrônicas realizadas em todo o território nacional;

- a assinatura digital terá sua autenticação e o reconhecimento certificados por órgão público que será regulamentado para este fim;

- a documentação eletrônica, bem como o cadastro das assinaturas digitais, deverão estar com seus registros disponíveis para avaliação e fiscalização dos órgãos federais responsáveis.

A Comissão Especial do Projeto de Lei formada para analisar o Projeto é composta pela Comissão de Defesa do Consumidor, Meio Ambiente e Minorias (CDCMAM), Comissão de Economia, Indústria e Comércio (CEIC) e a Comissão de Constituição e Justiça e de Redação (CCJR), tendo como relator o Deputado Julio Semeguini.

O Projeto de Lei no 1589/99 do Deputado Luciano Pizzatto (OAB/SP) dispõe sobre o comércio eletrônico, a validade jurídica dos documentos eletrônicos e a assinatura digital. Também trata os seguintes assuntos:

- informações prévias prestadas pelo ofertante e informações solicitadas ao destinatário;

- contratação eletrônica, intermediários, proteção e defesa do consumidor;

- documentos eletrônicos, eficácia jurídica:

- a certificação de chave pública feita por tabelião, Certificado Público, faz presumir sua autenticidade; - a certificação de chave pública feita por particular, Certificado Privado, não gera presunção de autenticidade perante terceiros.

- responsabilidades dos tabeliães;

- autoridades competentes para autorização e fiscalização;
- sanções administrativas e sanções penais;

Este Projeto de Lei foi anexado ao Projeto de Lei ํo 1483/99.

O Projeto de Lei do Senado no 00672/99 apresentado pelo Senador Lúcio Alcântara também trata do comércio eletrônico, encontrando-se em fase mais adiantada do que os Projetos de Lei anteriormente discutidos. O Senador José Fogaça foi o relator do Projeto de Lei oferecendo em 20/06/2000 parecer favorável em seu relatório estando matéria pronta para a pauta da Comissão de Constituição, Justiça e Cidadania (CCJ).

O Projeto de Lei no 0022/96 do Senador Sebastião Rocha, atual Projeto de Lei no 3173/97 na Câmara de Deputados, dispõe sobre documentos produzidos e os arquivados em meio eletrônico atribuindo valor jurídico aos mesmos e dá outras providências. Aprovado no Senado Federal, foi encaminhado em 28/05/1997 para Câmara de Deputados encontrandose atualmente na Comissão de Constituição e Justiça e de Redação aguardando o parecer do Relator Deputado José Roberto Batochio.

O Projeto de Lei o 1532/99 da Deputada Angela Guadagnin dispõe sobre a elaboração e arquivamento de documentos em meios eletromagnéticos. Desde o dia 21/09/1999 encontra-se na Comissão de Educação, Cultura e Desportos (CECD) aguardando parecer do Relator Deputado Nilson Pinto.

\section{CONCLUSÃO}

A existência de legislação e normatização específicas sobre o uso de documentos eletrônicos é imprescindível para que a contabilidade possa utilizar todo o potencial oferecido pelas novas tecnologias de informação.

O reconhecimento legal da assinatura digital é a maior lacuna para que o documento eletrônico possa ser amplamente utilizado no processo contábil. Relacionado a isto, surge a questão do valor probatório dos dados arquivados e disponíveis sob uma forma digital, principalmente nos casos em que a forma exigida por lei prevê somente o uso de papel como suporte da informação.

Conforme discorrido anteriormente, entende-se por documento todo o registro de um fato, e se esse fato pode ser comprovado, naturalmente que o seu valor probatório é o mesmo que qualquer outro documento preso a um meio físico, e repete-se que a Assinatura 
Digital trará a segurança esperada para a contabilidade e, principalmente, todos os seus usuários.

É evidente que a nova realidade impõe a chegada de meios seguros para o reconhecimento desses registros, mas, ultrapassada esta barreira, não vemos empecilho para a sua validade. Entretanto, devido à mobilidade constante e ao dinamismo da tecnologia de informação, é preciso deixar aberto um espaço suficiente para a liberdade de auto-regulamentação da matéria.

Dessa forma, é imprescindível que a comunidade contábil acompanhe todo este processo legislativo, pois se trata de uma matéria que modificará o atual processo contábil, transformando o contador em um verdadeiro analista de informação.

O uso de documentos eletrônicos, bem como da Internet, nos coloca uma série de novas questões na Contabilidade, como por exemplo novas formas de Evidenciação. Assim, se desejarmos ficar competitivos como profissão, devemos manter-nos informados de toda esta nova tecnologia que vem modificando a forma com que as empresas fazem negócio e, conseqüentemente, impactando o processo contábil como um todo.

REFERÊNCIAS BIBLIOGRÁFICAS

AVEDON, Don M., Ged de a a z: tudo sobre gerenciamento eletrônico de documentos ; tradução Roberta da Sulva Aquino, São Paulo : CENADEM, 1999.

DIfFIE, E, HELLMAN, M.E. New directions in criptography. IEEE, 1976

FIPECAFI, e ARTHUR ANDERSEN. Normas e práticas contábeis no Brasil. 2. ed., São Paulo: Atlas, 1997.

GARCÍA GUTIÉRREZ, Antonio Luis. Lingüística documental. Barcelona : Mitre, 1989

GIANNANTONIO, E. Manuale di ciritto dell'Informatica. Padova, 1994.

HENDRIKSEN, Eldon S., VAN BREDA, Michael F. Teoria da contabilidade; tradução de Antonio Zoratto Sanvicente. São Paulo: Atlas, 1999.

IUDÍCIBUS, Sérgio de. Teoria da contabilidade. 5. ed., São Paulo: Atlas, 1997.

KURZ, Robert. A virtualização da economia mercados financeiros transnacionais e a crise da regulação. Folha de São Paulo, São Paulo, 23 maio 1999. p. 14.

MATTESSICH, R. Critique of Accountting: examination of the foundations and normative structure of an applied discipline . London: Quorunm Books, 1995.

MENNINGER, K. Number words and number symbols: a cultural history of numbers. New York: Dover Publications, 1969.

MICCOLI, Mario. Cybernotary. consiglio nazionale del notariato - Forum di Informatica Giuridica

MORELLO, A. Sottoscrizione. In Nov. Dig. It. XVII, Torino, 1970.

MORTON, Michael S.Scott. The Corporation of the 1990s: information technology and organizational Transformation. Oxford University Press, 1991.

REQUIÃO, Rubens. Curso de direito comercial, Vol. 1, 23. ed., São Paulo: Saravia, 1998.

STRINGHER, Ademar, Aspectos legais da documentação em meios micrográficos, magnéticos e ópticos. 2. ed., São Paulo : Universidade Ibirapuera, 1996.

VALVERDE, Trajano de Miranda. Força probante dos livros mercantis, Rio de Janeiro: Forense, 1960.

ZAGAMI, Raimondo. Firme 'Digitali', crittografia e validità del documento elettronico. In "II Diritto dell'informazione e dell'informatica", 1996, fasc. 1. 